\title{
Mycobiota Associated with Imported Seeds of Vegetable Crops in Sudan
}

\author{
Sohair A. Abdelwehab ${ }^{1}$, Saifeldin A.F. El-Nagerabi ${ }^{2, *}$ and Abdulqadir E. Elshafie ${ }^{3}$ \\ ${ }^{1}$ Department of Botany, Faculty of Science, University of Khartoum, PC, 555, P.O. Box 321, Sudan \\ ${ }^{2}$ Department of Biological Sciences and Chemistry, College of Arts and Sciences, University of Nizwa, P.O. Box 33, PC \\ 616, Birkat Al Mouz, Nizwa, Oman \\ ${ }^{3}$ Department of Biology, College of Science, Sultan Qaboos University, P.O. Box 36, AlKhoudh, Postal Code 123, Oman
}

\begin{abstract}
Seedborne fungi present on or inside the seed or as contaminant with the seed debris adversely affect seed viability, germination, emergence, plant growth vigour and eventually production and productivity. In the present study, seedborne fungi of 7 imported vegetables were examined. 29 species of fungi belonging to 23 genera were recovered from the seeds. Of these fungi, 6 species and one genus are new records to the mycoflora of Sudan, whereas different species are new to the micobiota of these vegetables. These include 15 species for Beta vulagris, Petroselinum crispum (14 species), Solanum melongena (12 species), Portulaca oleracea (8 species and 1 genus), Eruca sativa (5 species and 3 genera), Corchorus olitorius (2 species), and Cucumis sativa (1 species). The seeds were highly contaminated with saprophytic and pathogenic fungi (25-100\%), which apparently inhibited seed germination (15-79\%) and seedling emergence (12-75\%) of these vegetables. The genus Aspergillus and Drechslera (4 species each) were the most prevalent genera followed by Alternaria, Curvularia, Fusarium, Pithomyces (2 species) and 1 species for the remaining genera (Aureobasidium, Beltrania, Chaetomium, Cladosporium, Memnoniella, Microascus, Rhizopus, Sordaria, Stachybotrys, Stemphylium, Trichothecium, Ulocladium, and Wellernia). Therefore, there is urgent need for development of proper standard laboratory seed testing methods, fungal eradication measures, and adopting strong legislations and quarantine regulations. The use of certified and high grade seeds is a priority.
\end{abstract}

Keywords: Beta vulagris, Corchorus olitorius, Cucumis sativa, Eruca sativa, Petroselinum crispum, Portulaca oleracea, Seedborne fungi, Solanum melongena, Sudan.

\section{INTRODUCTION}

Vegetables are the fresh edible parts of herbaceous plants. They are important food of significant nutritive value for their high carbohydrates, vitamins, fibers, mineral contents, which associated with maintenance of health and disease prevention. They may be edible roots, stems, leaves, fruits or seeds [1-3]. Many studies have reported their uses and consumption methods [4-6].

In Sudan, various vegetables are grown in both irrigated and rain-fed plots, in a total area of about 273000 hectares which represents $3 \%$ of the total cultivated area with average production of about 3.4 million tons of vegetables [7]. Generally, The horticultural crops represent $12 \%$ of the national agricultural income compared to $17 \%$ cotton and $29.6 \%$ cereals and oil seeds. Introduction of exotic species and varieties of vegetables started early, mainly from Egypt, USA, Denmark, Holland, France and other countries [8]. Beta vulgaris L. (Beet, Selg) of the family Amaranthaceae is known as beet root and the leaves and roots eaten as salads

*Address correspondence to this author at the Department of Biological Sciences and Chemistry, College of Arts and Sciences, University of Nizwa, P.O. Box 33, PC 616, Birkat Al Mouz, Nizwa, Oman;

Tel: + (968) 2544-6825; Fax: + (968) 2544-3050;

E-mail: nagerabi@unizwa.edu.om or pickled, and as folk medicine in many parts of the World. Corchorus olitorius L. (Malvaceae), jute, Jew mallow "Molukhiyah" in Arabic, "Khudra" means "green" in Sudanese Arabic, is cooked as green leaf vegetable in most countries of the Middle East, North Africa, and some African countries. The seeds and leaves extracts of $C$. olitorius possess antibacterial activity against wide range of bacterial species $[9,10]$. Cucumis sativa $\mathrm{L}$. (Cucumber) of the family Cucurbitaceae is a common cultivated vegetable with many different varieties and grown in green houses and outdoors. Eruca sativa Mill (Brassicaceae) is known as garden rocket or "Gargeer" in Arabic and is cultivated in many places throughout the World as vegetable salad. Petroselinum crispum Mill (Parsley) of the family Apiaceae is an herb that is widely cultivated in temperate, subtropical and tropical areas as spice and vegetable salad. Portulaca oleracea L. (Portulaceae) which is known as purslane "Rigla" or "Begla" in Arabic is edible and used fresh as salad or cooked as a vegetable similar to Spinach. It is also used in traditional Chinese folk medicine and in many regions it is considered as invasive weed [11]. It has been reported to have antifungal and antibacterial activities [12-14]. Solanum melongena L. (Eggplant, Aubergine), Bazenjan" in Arabic belongs to Solanaceae with raw fruits cooked or roasted in oil until charred and used as food for many countries in Asia, Middle East, North and South Africa. 
Fungi are the principal organisms associated with seeds causing devastating effects on seed germination, seedlings emergence, plant growth vigour and eventually quality and quantity of the production. In the Sudan, seeds for cultivation of vegetables are imported from different countries of various climatic conditions. Therefore, various studies were conducted on vegetables diseases aiming at improving their productivity and to enhance their uses and market value. However, the seedborne fungi of Petroselinum crispum (Parsley), Portulaca oleracea (Purslane) and Solanum melongena (Eggplant) were not studied. Nonetheless, a number of fungal diseases have been reported infecting $P$. crispum [15-19], and $P$. oleracea $[11,20,21]$. On the other hand, numerous fungi were reported as seedborne and seed transmitted causing many diseases to B. vulgaris [22-24], and phylloplane and seedborne mycoflora of $C$. olitorius were reported [25, 26]. Many fungi were reported as seedborne fungi of $C$. sativa [27-29]. Many fungi were either isolated from the seeds of E. sativa $[30,31]$ or as foliar and root diseases [32-36]. In Sudan, there is increasing demand for production of high quality vegetable crops for both local consumption and export. This depends mainly on the use of healthy seeds which are free from seedborne pathogenic fungi. Therefore, seed health testing for fungi is an important practice and step towards management of plant diseases [37]. In Sudan, vegetable seeds are imported by local seed companies under low level of quarantine regulations and seed testing facilities. Besides, no research has been conducted on the seedborne mycoflora of these vegetables and little to negligible information available on their diseases. Therefore, the present study was undertaken to improve recognition and to assess the quality and the incidence of seedborne mycobiota associated with seven imported vegetable crops namely Beta vulagris, Corchorus olitorius, Cucumis sativa, Eruca sativa, Petroselinum crispum, Portulaca oleracea, and Solanum melongena and to evaluate their effect on seed germination and seedlings emergence levels. This will enrich our knowledge about the nature of these fungi and contribute to effective control measures through adopting strong quarantine regulations and efficient seed testing methods.

\section{METHODS}

\section{Collection of the Seed Samples}

The seed samples of 7 vegetable crops, namely Beta vulagris (Beet, Selg), Corchorus olitorius (Jew mallow), Cucumis sativa (Cucumber), Eruca sativa (Rocket salad), Petroselinum crispum (Parsley), and Portulaca oleracea (Purslane, Rigla), which were imported from Egypt and Solanum melongena (Eggplant) from Holland (Netherlands), were purchased from seed companies in Khartoum State, Sudan. The working samples were drawn and examined according to rules of the International Seed Testing Association [38].

\section{Seed Germination}

In this study, the blotter method was used according to the rules of the International Seed Testing Association [38].
For this, 400 seeds from each sample were inoculated on sterilized moistened filter paper in Petri dishes (Blotter). The seeds were spaced according to their size at equal distance. The inoculated plates were incubated in Gallenkamp illuminated incubator at $26^{\circ} \mathrm{C}$ under alternating cycle of 12 hours near ultraviolet light and darkness to stimulate fungal sporulation of many of the seedborne fungi [38]. The incubated seeds were kept moistened by adding sterile distilled water throughout the incubation period (7-15 days) and the percentage of seed germination was recorded.

\section{Emergence of Seeds in Soil}

For testing the emergence levels of the seeds from the soil, 200 seeds from each type of the selected vegetables were sown in pots filled with uniform mixture of sand and silt (2:1). The seeds were covered with soil layer of $1-3 \mathrm{~cm}$ deep depending on the seed size. The seeds were sown at the rate of 20 seeds per pot and were kept in the Botanical garden of the Department of Botany, University of Khartoum, which is of partial shade and average temperature of between $27^{\circ} \mathrm{C}$ and $29^{\circ} \mathrm{C}$. The average percentage of seed emergence was recorded for each vegetable crop.

\section{Isolation and Estimation of Fungi}

For isolation of the seedborne fungi, routine agar plate method which was suggested by many authors was adopted [39-41]. In this method, 400 seeds from each sample were surface disinfected in $1 \%$ sodium hypochlorite for $5 \mathrm{~min}$ and washed with several changes of sterile distilled water. The treated seeds were then inoculated aseptically on Potato Dextrose Agar (PDA) and incubated at $28^{\circ} \mathrm{C} \pm 2^{\circ} \mathrm{C}$ for $1-2$ weeks. Then, the colonies of fungi which were developed around the seeds were examined, identified microscopically and the average levels of contamination and fungi incidence were recorded. The identification of the isolated fungi was confirmed using many taxonomic books, monographs and taxonomic papers [42-49]. For non-sporulating fungi, mycelial fragments were inoculated on Malt Extract Agar (MEA) and incubated at $28^{\circ} \mathrm{C} \pm 2^{\circ} \mathrm{C}$ to stimulate sporulation of these fungi and were then identified to species level. Some of these fungi were illustrated (Appendices: Fig. 1-22).

\section{RESULTS AND DISCUSSION}

Twenty nine species of fungi belonging to 23 genera were isolated from seeds of the 7 imported vegetables viz. Beta vulagris (Beet, Selg), Corchorus olitorius (Jew mallow), Cucumis sativa (Cucumber), Eruca sativa (Rocket salad), Petroselinum crispum (Parsley), Portulaca oleracea (Purslane, Rigla), and Solanum melongena (Eggplant) (Table 1). Of these isolates, 6 species and one genus are new records for the mycoflora of Sudan, whereas different species are considered new for the seeds of each vegetable (Table 1). These seeds were highly contaminated with saprophytic and potentially pathogenic fungi $(25-100 \%)$ and exhibited very low levels of seed germination (15-79\%) and seedling emergence (12-75\%) (Table 2). The genus Aspergillus and Drechslera (4 species each) were the most dominant genera followed by Alternaria, Curvularia, Fusarium, Pithomyces (2 species) and one species for the 
Table 1. Incidence percentage of fungi in different vegetables seeds.

\begin{tabular}{|c|c|c|c|c|c|c|c|c|c|}
\hline \multirow[b]{2}{*}{ Isolates } & \multirow[b]{2}{*}{ 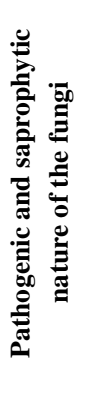 } & \multicolumn{8}{|c|}{ Incidence \% } \\
\hline & & 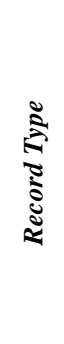 & 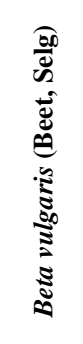 & 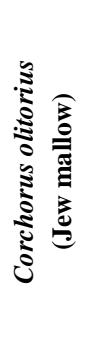 & 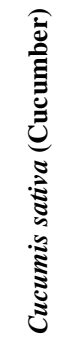 & 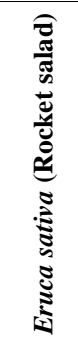 & 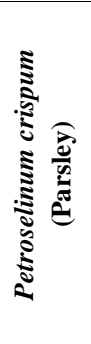 & 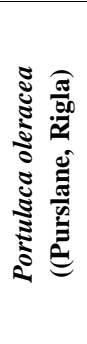 & 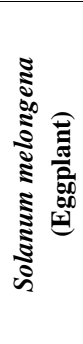 \\
\hline Alternaria alternata (Fig. 1) & $\mathrm{P}^{4}$ & & 1 & 3.0 & -1 & $2.0 *$ & 2.25 & $3.0 *^{2}$ & - \\
\hline Alternaria citri (Fig. 2) & $\mathrm{P}$ & & - & - & - & - & $5.75 *$ & - & - \\
\hline Aspergillus spp. & $\mathrm{PS}^{6}$ & & 5.0 & 2.0 & 1.0 & $3.0 *$ & 2.0 & 2.5 & 3.5 \\
\hline Aspergillus flavus & $\mathrm{P}$ & & 8.5 & 1.5 & 1.25 & $4.0 *$ & 1.0 & $3.5^{*}$ & $1.25^{*}$ \\
\hline Aspergillus nidulans & $\mathrm{P}$ & & 10.25 & - & 2.0 & - & $1.0 *$ & - & $2.5 *$ \\
\hline Aspergillus niger & $\mathrm{P}$ & & 3.75 & 2.0 & 5.0 & - & $4.25^{*}$ & - & $11.0^{*}$ \\
\hline Aspergillus terreus & $\mathrm{S}^{5}$ & & 1 & 3.0 & 1.0 & - & - & $1.0 *$ & $3.5^{*}$ \\
\hline Aureobasidium pullulans (Fig. 3) & S & & $2.75^{*}$ & 1.0 & - & - & - & $4.0^{*}$ & - \\
\hline Beltrania santapui (Fig. 4) & $\mathrm{S}$ & $\mathrm{NS}^{3}$ & $1.0^{*}$ & - & - & - & - & - & - \\
\hline Chaetomium sp. & PS & & - & - & - & - & 1.0 & - & - \\
\hline Chaetomium globosum (Fig. 5) & $\mathrm{P}$ & & $2.25^{*}$ & $1.0 *$ & 1.25 & - & $1.0^{*}$ & - & $1.0 *$ \\
\hline Cladosporium spp. & PS & & 2.5 & - & - & - & 5.25 & - & 4.75 \\
\hline Cladosporium cladosporiodes (Fig. 6) & S & & - & - & - & $1.75^{*}$ & $9.75^{*}$ & $11.0^{*}$ & $3.0^{*}$ \\
\hline Curvularia lunata (Fig. 7) & $\mathrm{P}$ & & $2.25^{*}$ & - & - & - & $2.25^{*}$ & $3.0 *$ & $3.5^{*}$ \\
\hline Curvularia pallescens (Fig. 8) & $\mathrm{P}$ & & $1.0 *$ & - & - & - & $1.0^{*}$ & - & - \\
\hline Drechslera hawaiensis (Fig. 9) & $\mathrm{P}$ & & - & - & - & - & - & - & - \\
\hline Drechslera papendorfii (Fig. 10) & $\mathrm{P}$ & & $2.0 *$ & - & - & - & - & - & - \\
\hline Drechslera spicifera (Fig. 11) & $\mathrm{P}$ & & $1.0 *$ & - & - & - & $1.0 *$ & - & - \\
\hline Drechslera rostrata (Fig. 12) & $\mathrm{P}$ & & $2.0 *$ & - & $2.5^{*}$ & - & $1.0 *$ & $2.5 *$ & - \\
\hline Eurotium sp. & PS & & 1.0 & - & - & - & - & - & - \\
\hline Fusarium semitectum (Fig. 13) & $\mathrm{P}$ & & - & - & - & - & $2.0 *$ & - & - \\
\hline Fusarium solani (Fig. 14) & $\mathrm{P}$ & & - & - & - & - & - & - & $1.0 *$ \\
\hline Lophotrichus sp. & PS & NS & $1.0 *$ & - & 1.0 & - & - & - & - \\
\hline Memnoniella echinata (Fig. 15) & $\mathrm{S}$ & NS & $2.0 *$ & $5.0 *$ & 1.75 & - & $2.75 *$ & $1.0 *$ & $1.0 *$ \\
\hline Microascus trignosporus (Fig. 16) & $\mathrm{S}$ & & $1.0^{*}$ & - & - & - & - & - & - \\
\hline Penicillium spp. & PS & & 1.25 & - & - & $2.0 *$ & 1.25 & 1.0 & 1.25 \\
\hline Phoma sp. & PS & & 1.25 & - & - & $1.75 *$ & - & $3.0 *$ & - \\
\hline Pithomyces chartarum (Fig. 17) & $\mathrm{P}$ & NS & $1 *$ & - & - & - & - & - & - \\
\hline
\end{tabular}


Table 1. contd...

\begin{tabular}{|c|c|c|c|c|c|c|c|c|c|}
\hline \multirow[b]{2}{*}{ Isolates } & \multirow[b]{2}{*}{ 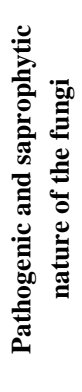 } & \multicolumn{8}{|c|}{ Incidence \% } \\
\hline & & 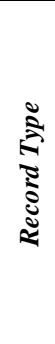 & 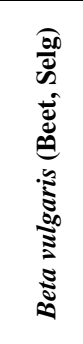 & 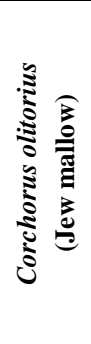 & 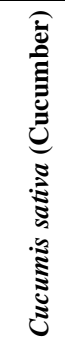 & 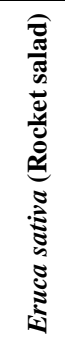 & 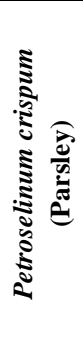 & 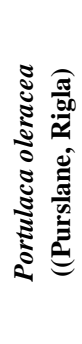 & 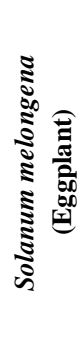 \\
\hline Rhizopus stolonifer & $\mathrm{S}$ & & 2.0 & - & 2.5 & - & $3.0 *$ & - & $1.0 *$ \\
\hline Sordaria fimicola & $\mathrm{S}$ & NS & $1.0 *$ & - & - & - & - & - & - \\
\hline Stachybotrys aurantes (Fig. 19) & $\mathrm{S}$ & & - & - & - & $3.0 *$ & - & - & - \\
\hline Stemphylium botryosum (Fig. 20) & $\mathrm{P}$ & & - & - & - & - & $3.0 *$ & - & $2.25^{*}$ \\
\hline Trichothecium roseum (Fig. 21) & $\mathrm{S}$ & & $1.25^{*}$ & - & - & - & - & - & - \\
\hline Ulocladium botrytis (Fig. 22) & $\mathrm{S}$ & & $5.75^{*}$ & - & 1.75 & $2.5^{*}$ & $2.25 *$ & - & - \\
\hline Wellernia sebi & $\mathrm{S}$ & NS & - & - & - & - & - & - & $2.0^{*}$ \\
\hline Mycelia sterilia & & & 3.0 & 2.0 & 1.5 & 3.5 & 2. & 1.0 & 4.0 \\
\hline
\end{tabular}

${ }^{1}$-: Not detected.

${ }^{2}$ : New record for the vegetable crop.

${ }^{3} \mathrm{NS}$ : New record for the mycoflora of Sudan.

Table 2. Average contamination, germination and emergence of different vegetables seeds.

\begin{tabular}{|l|c|c|c|}
\hline \multicolumn{1}{|c|}{ Seed Types } & Contamination \% & Germination \% & Emergence \% \\
\hline \hline Beta vulgaris & 55 & 65 & 72 \\
\hline Corchorus olitorius & 25 & 15 & 12 \\
\hline Cucumis sativa & 100 & 68 & 62 \\
\hline Eruca sativa & 35 & 64 & 60 \\
\hline Petroselinum crispum & 40 & 79 & 75 \\
\hline Portulaca oleracea & 30 & 77 & 60 \\
\hline Solanum melongena & 27 & & \\
\hline
\end{tabular}

remaining genera (Aureobasidium, Beltrania, Chaetomium, Cladosporium, Memnoniella, Microascus, Rhizopus, Sordaria, Stachybotrys, Stemphylium, Trichothecium, Ulocladium, and Wellernia).

Many researchers are studying the seedborne and plant pathogenic fungi of different crops including vegetables. Of the negligible studies of $B$. vulgaris (Beet), Pérez Vicente et al. (2011) [24] stated that Verticillium dahliae and $V$. albo-atrum are seedborne and seed transmitted of this vegetable. A number of fungi were reported causing different diseases to this plant which include; Phoma betae (Leaf spot) [22]; Fusarium oxysporum f.sp. betae (Fusarium yellow) [23], Cecospora beticola (Leaf spot) [50]. In the present study, 15 species and 12 genera Aureobasidium: pullulans, Beltrania santapui, Chaetomium globosum,
Curvularia lunata, C. pallescens, Drechslera papendorfii, D. spicifera, D. rostrata, Lophotrichus sp., Memnoniella echinata, Microascus trignosporus, Pithomyces chartarum, Sordaria fimicola, Trichothecium roseum, and Ulocladium botrytis were isolated for the first time as seedborne fungi of beet (Table 1). In the study of the phylloplane mycoflora of Corchorus olitorius [25] reported a number of fungi including Alternaria, Aspergillus, Cladosporium, Fusarium and Penicilliumm. In similar study, many fungi were reported as seedborne of $C$. olitorius such as Aspergillus spp. Penicillium spp., Macrophomina phaseolina, Fusarium oxysporum, F. moniliforme (G. fujikuroi) and Sclerotium rolfsii (Corticium rolfsii) [19]. In this investigation, 8 species of fungi (Alternaria alternata, Aspergillus spp., Aspergillus flavus, Aspergillus niger, Aspergillus terreus, Aureobasidium 
pullulans, Chaetomium globosum, Memnoniella echinata) were isolated from the seeds of $C$. olitorius and of these fungi Chaetomium globosum and Memnoniella echinata are new records to Jew mallow (Table 1). Some of the previously reported as seedborne and pathogenic fungi were recovered from the current seeds [9, 25] (Table 1). For cucumber (Cucumis sativa), 7 seedborne fungi were isolated from this vegetable in Bangladesh [28]). These include Aspergillus flavus, A. niger, Fusarium oxysporum, F. moniliforme, Penicillium spp., Doratomyces sp. and Rhizopus stolonifer which ranged from 1 to $17 \%$. Also A. flavus, A. versicolor, Chaetomium globosum, Cunninghamella sp., Curvularia lunata, Fusarium oxysporum, F. solani, F. verticillioides, Myrothecium roridum, Phoma spp., and Trichurus sp., were reported as seedborne of cucumber [27]. Moreover, Fusarium solani, Fusarium spp., A. niger, Colletotrichum spp., Macrophomina phaseolina, Rhizoctonia spp. were reported as seedborne fungi on cucumber seeds [29, 51, 52]. In the present study, Drechslera rostrata was newly isolated from cucumber seeds and some of the previously recorded seedborne fungi such as were recovered [27-29, 51, 52] (Table 1). In similar studies of seedborne fungi of Eruca sativa, A. flavus, A. niger, Penicillium chrysogenum, $P$. funiculosum, and Rhizopus stolonifer were reported as seedborne species [30]. Giberella fujikuroi was also reported as seedborne fungus [31], whereas other fungi were reported as foliar diseases such as Alternaria brassicae (Alternaria blight) [32], Peronospora parasitica (Downy meldews) and Albugo candida (white rust) [33], Plasmidio-phora brassicae (clubroot) [34], Sclerotinia sclerotiorum, Rhizoctonia solani, and Golovinomyces orontii [35], Fusarium equiseti (leaf spot) [36]. In this study, many of the common saprophytic seedborne fungi [41] were reisolated from the seeds of $E$. sativa including Alternaria alternata, A. flavus, Cladosporium spp., Phoma sp., Penicillium spp., Stachybotrys botryosum and Ulocladium botrytis (Table 1). No seedborne fungi were reported in/on the seeds of Petroselinum crispum. However, a number of fungi were associated with different diseases of this plant. Septoria blight [15], Phytophthora root rot [16], powdery mildews [17], Sclerotinia sclerotiorum [18], and downy mildews [19]. In this study, 14 species and 11 genera Alternaria alternata, Aspergillus flavus, A. nidulans, Chaetomium globosum, Cladosporium cladosporiodes, Curvularia lunata, $C$. pallescens, Drechslera spicifera, D. rostrata, Fusarium semitectum, Memnoniella echinata, Rhizopus stolonifer, Stemphylium botryosum, and Ulocladium botrytis were isolated as new records for parsley seeds (Table 1). Fungi on or inside the seeds of $P$. oleracea has never been reported. Nonetheless, many plant pathogenic fungi were known to infect this plant; Virticillium dahlia (Verticillium wilt) [11], the obligate parasite Wilsoniana portulacacae (white blister disease), Drechslera portulacae [20], and the highly pathogenic Dichotomphthora portulacae [21]. In the present report, 8 species and one genus are considered new seedborne fungi for this vegetable. These include Alternaria alternata, Aspergillus flavus, A. terreus, Aureobasidium plullans, Cladosporium cladosporiodes, Curvularia lunata, Drechslera spicifera, Memnoniella echinata, and Phoma sp.
(Table 1). The seedborne fungi of Solanum melongena (Eggplant) were not studied. Therefore, in this investigation 12 species of fungi including Aspergillus flavus, A. nidulans, A. niger, A. terreus, Chaetomium globosum, Cladosporium cladosporiodes, Curvularia lunata, Fusarium solani, Memnoniella echnata, Rhizopus stolonifer, Stemphylium botryosum, and Wellernia sebia are considered new for the mycoflora of eggplant (Table 1).

Many fungal species of saprophytic genera cause destructive diseases to various plants. Although, common genera like Alternaria, Aspergillus, Chaetomium, Cladosporium, Curvularia, Drechslera, Fusarium, Mucor, Penicillium, Rhizopus, and Ulocladium are saprophytic in nature, some species of these genera can cause serious plant diseases [39-41, 51]. In our investigations, many species of these genera were recovered from the seeds of the imported vegetables (Table 1) and displayed high levels of seed contamination (25-100\%) which adversely affect the seed viability and associated with low levels of germination (15$79 \%$ ), and seedling emergence $(12-75 \%)$ as concluded by many authors $[51,53]$. In similar studies on different plants, these fungi were reported to cause various plant diseases; leaf lesion of Poa paratensis (Curvularia pallescens), seed rot of Sorghum bicolor (Drechslera spicifera), leaf spot on wide host range (D. rostrata), seedling blight (Curvularia lunata), and Fusarium solani wilt [54].

\section{CONCLUSION}

The nature of fungi associated with the seeds of 7 imported vegetable crops and their effects on seed germination, seedling emergence was were studied. The seeds were highly contaminated with saprophytic and pathogenic fungi $(25-100 \%)$ which evidently reduced seed germination (15-79\%), and seedling emergence (12-75\%). Some of these fungi are new records to the seed mycoflora of these vegetables and to the fungal flora of Sudan. Since these fungi can be naturally present in the seeds, their hazardous effects on plant growth vigour and productivity warrant further investigations on their control. Therefore, it is apparently important to develop and implement ecofriendly and effective eradication measures for these seedborne contaminants. The development of proper seed testing methods, and strong quarantine regulations for import and export is a priority.

\section{CONFLICT OF INTEREST}

The authors confirm that this article content has no conflicts of interest.

\section{ACKNOWLEDGEMENTS}

We thank the Department of Botany, Faculty of Science, University of Khartoum for providing space and facilities to carry this research. Dr. Peter Cowan of the Department of Biological Sciences and Chemistry, University of Nizwa, improved the scientific content of the manuscript. Dr. Tom Hughes of University of Nizwa Writing Center proof read the English of this manuscript. 


\section{APPENDICES}

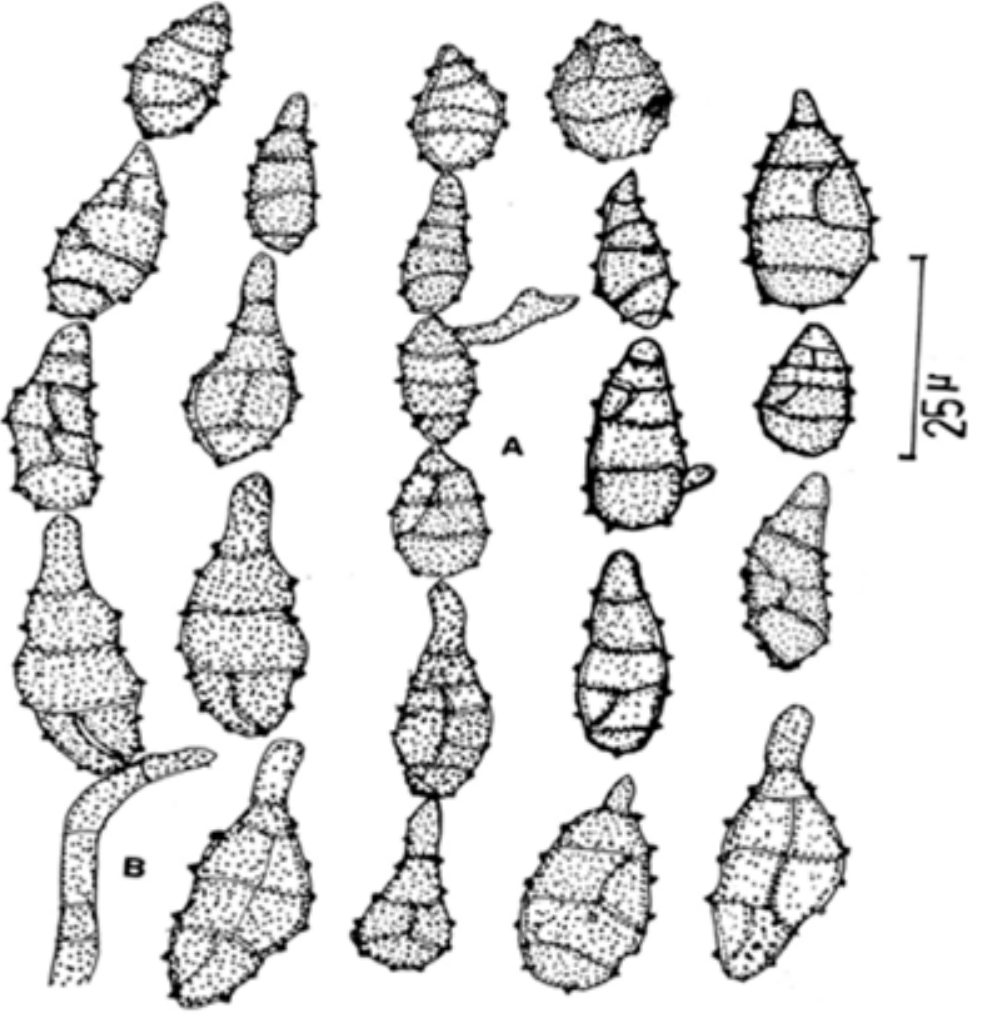

Fig. (1). Alternaria alternata (A) Conidia (B) Conidiophores.

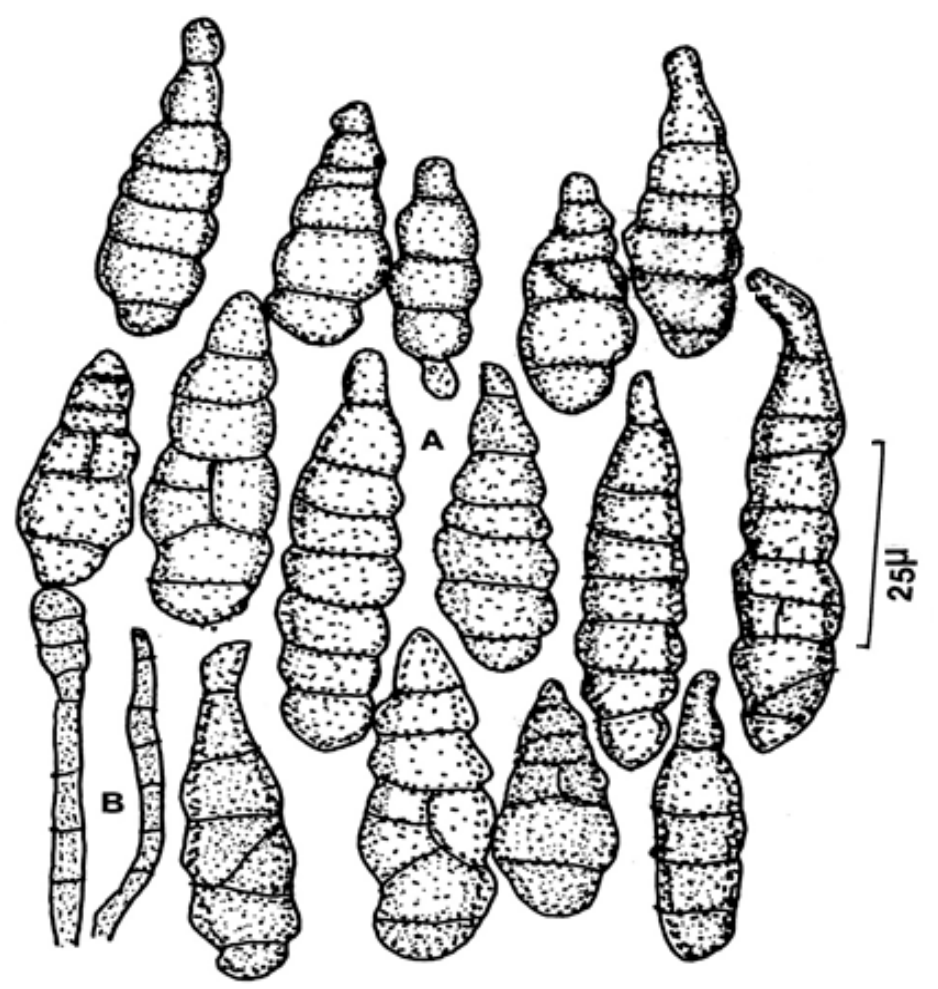

Fig. (2). Alternaria citri (A) Conidia (B) Conidiophores. 


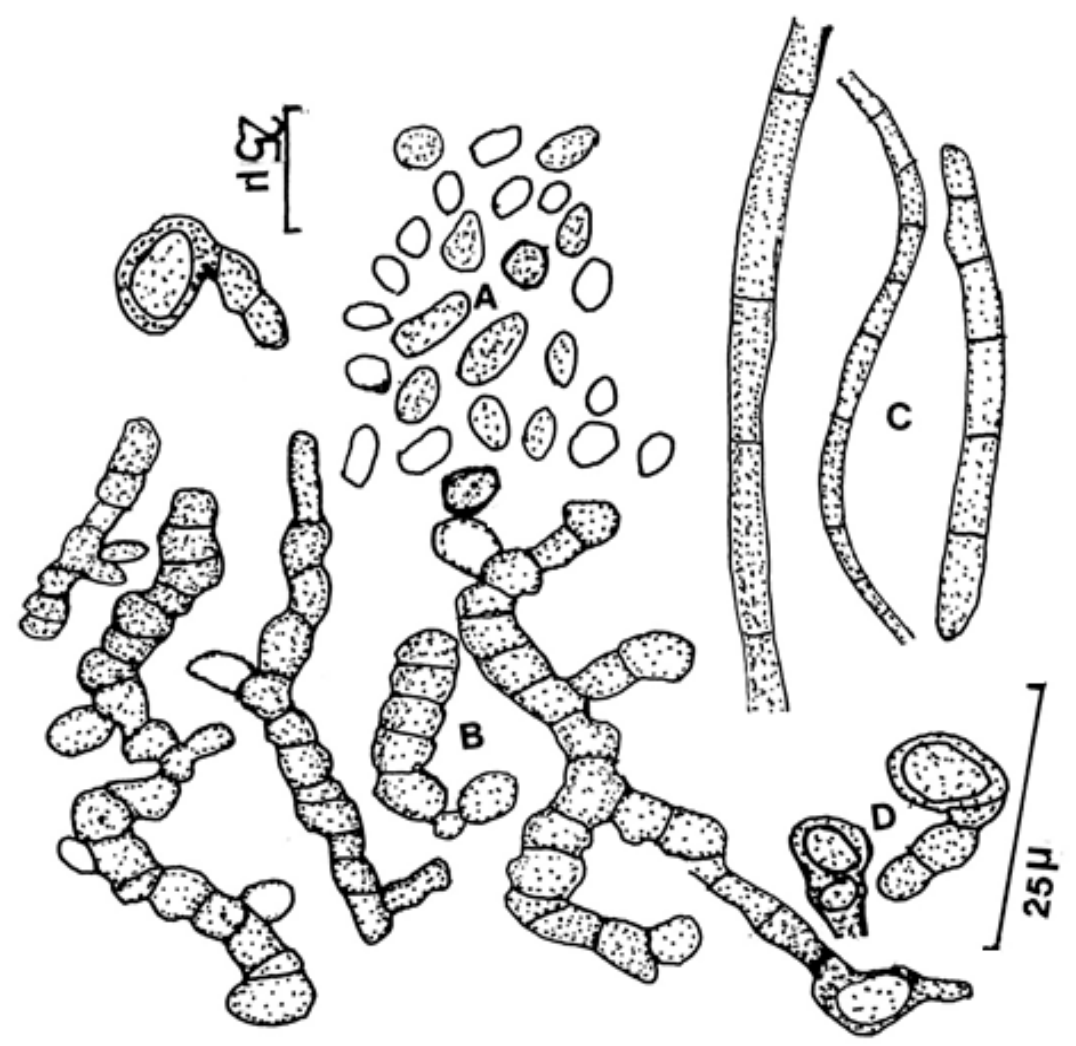

Fig. (3). Aureobasidium pullulans (A) Conidia (B) Conidiophores (C) Hyphae (D) Chlamydospore-like cells.

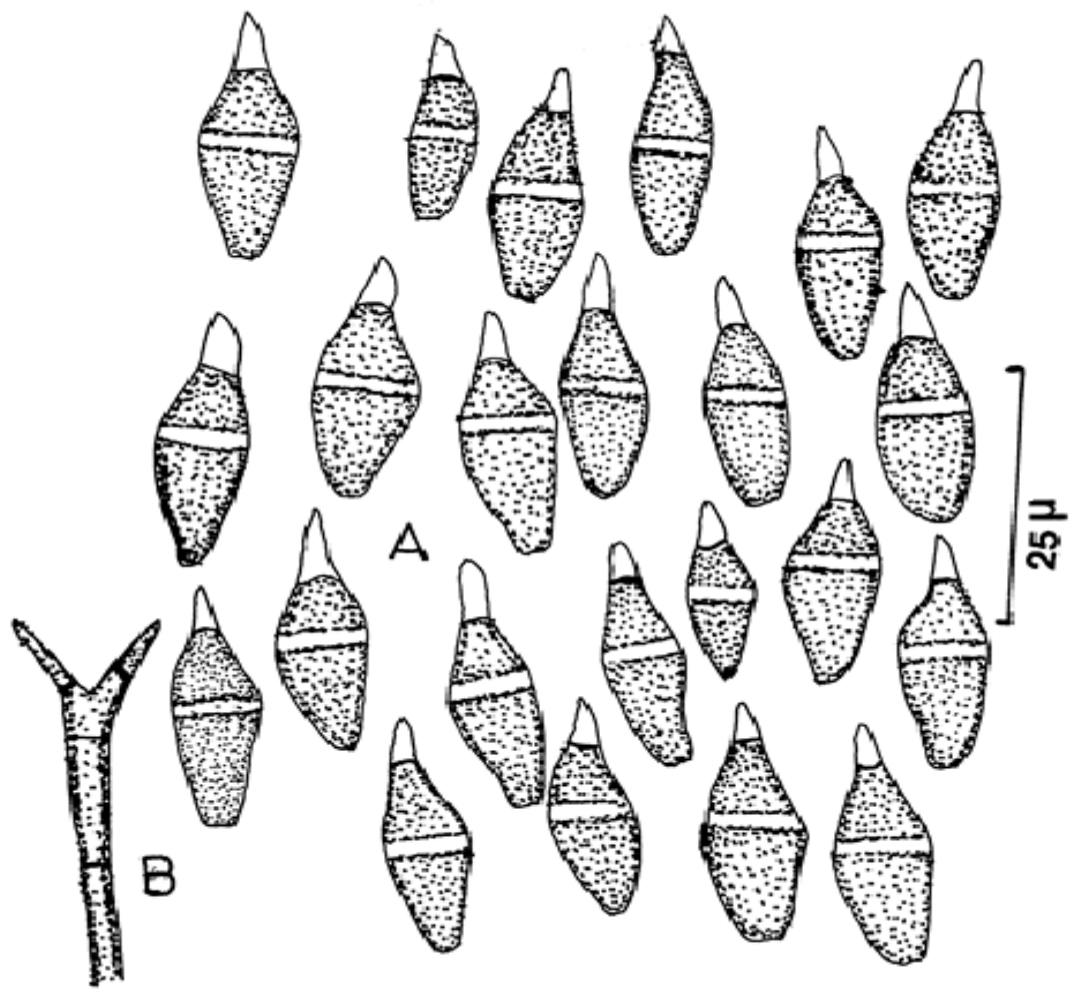

Fig. (4). Belterania santapui (A) Conidia (B) Conidiophores. 


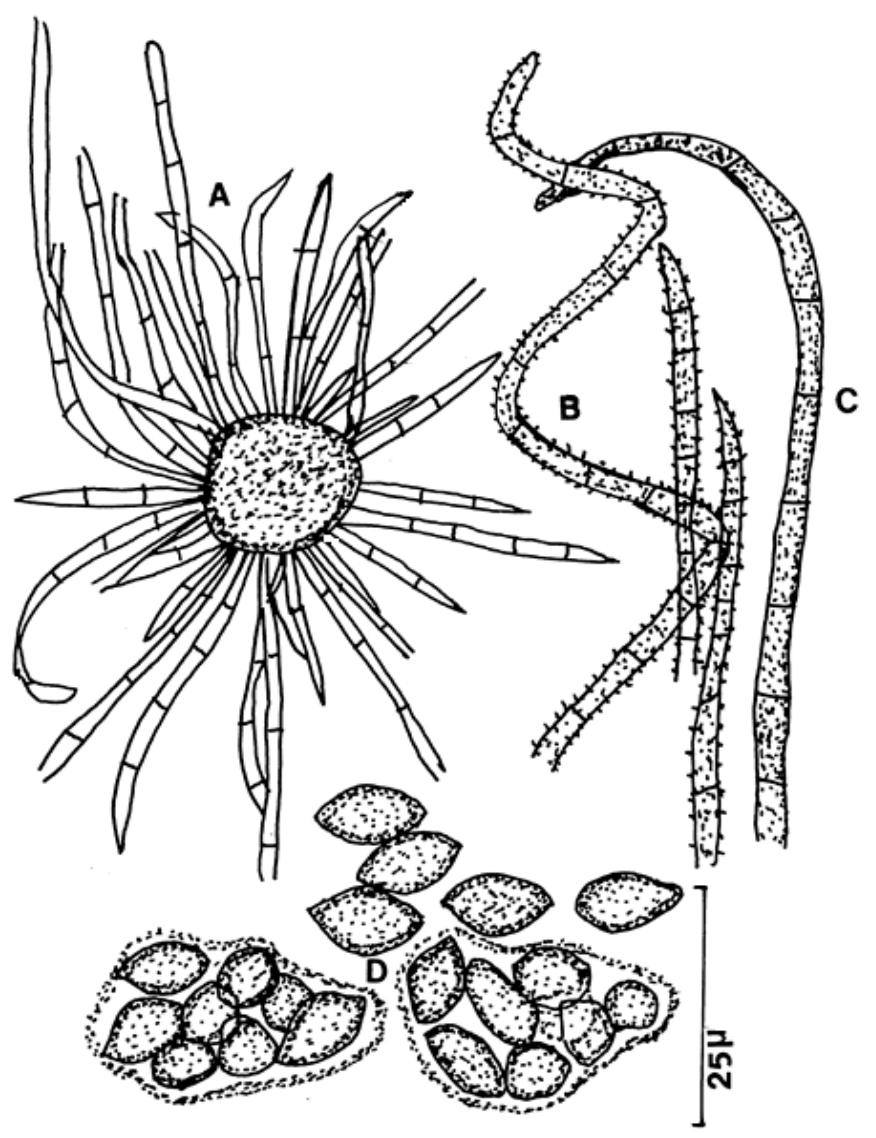

Fig. (5). Chaetomium globosum (A) Perithecium (B) Terminal hairs (C) Lateral hairs (D) Asci \& ascospores.

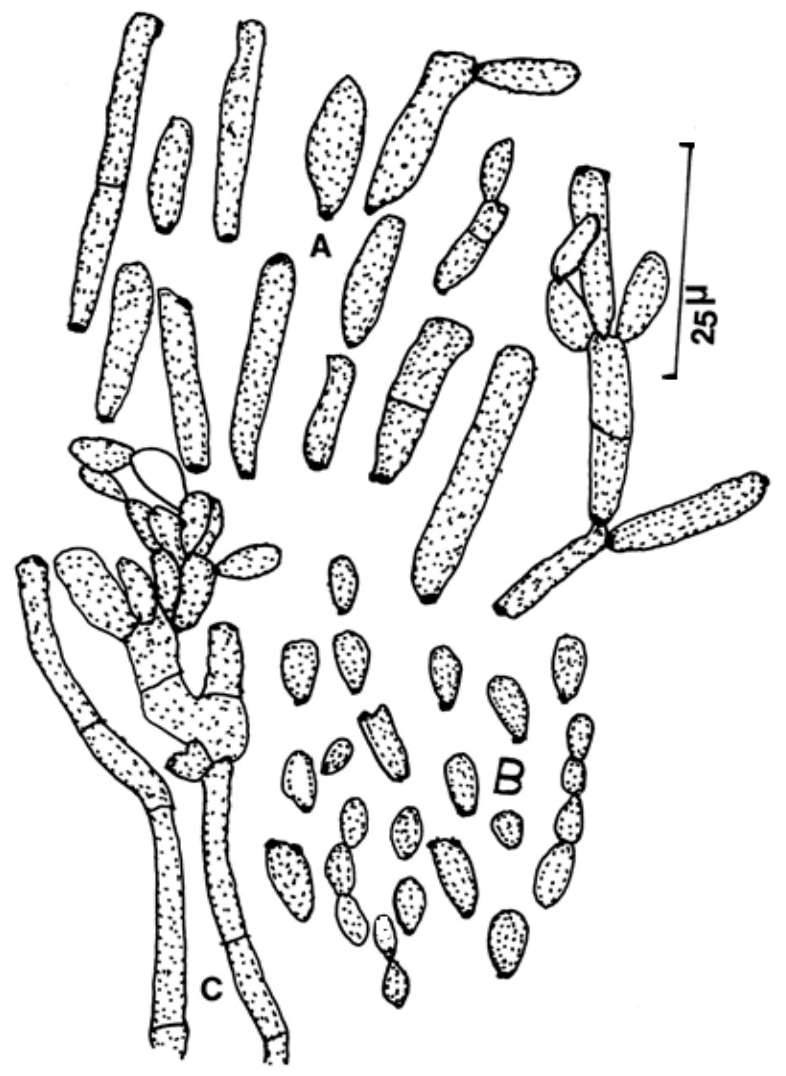

Fig. (6). Cladosporium cladosporiodes (A) Ramoconidia (B) Conidia (C) Conidiophores. 


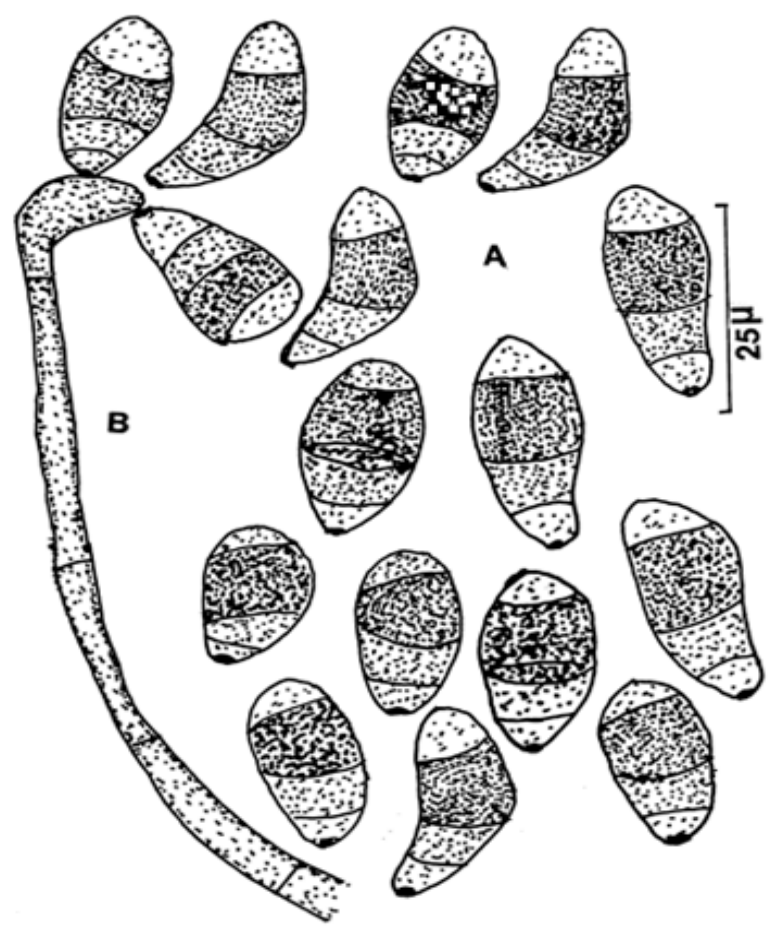

Fig. (7). Curvularia lunata (A) Conidia (B) Conidiophores.

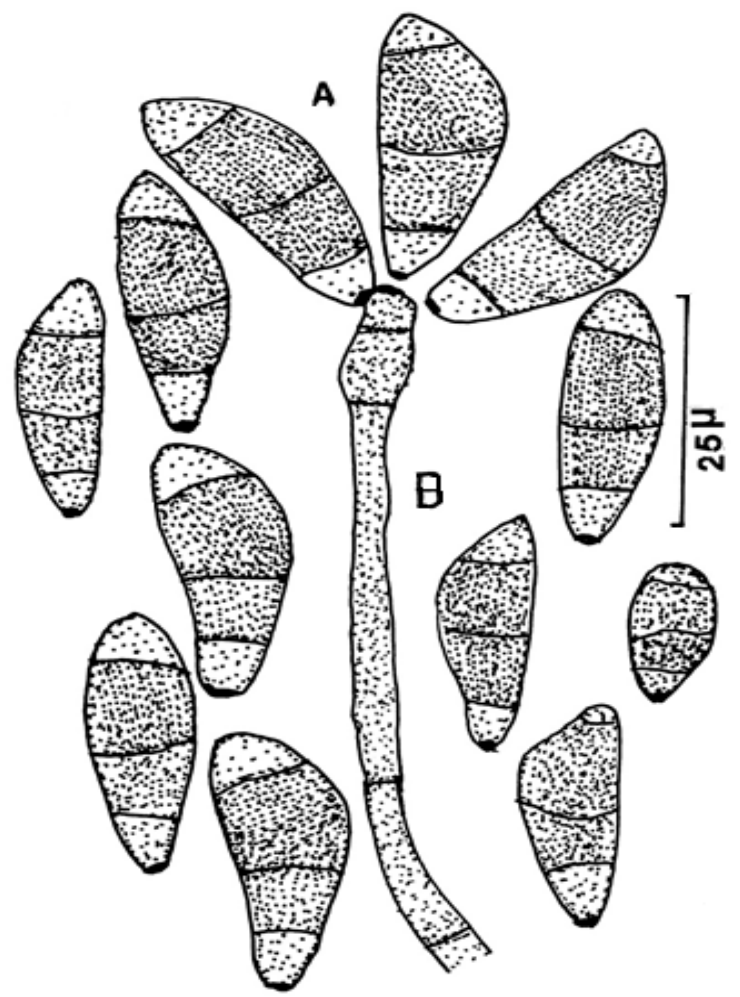

Fig. (8). Curvularia pallescens (A) Conidia (B) Conidiophores. 


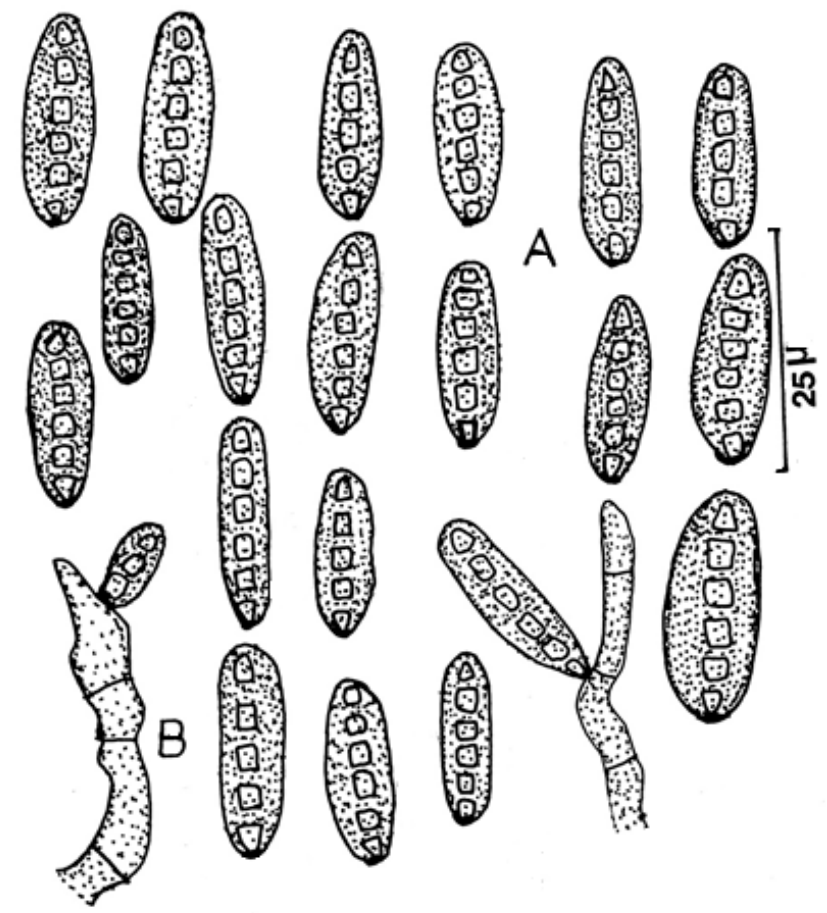

Fig. 9: Drechslera hawaiensis (A) Conidia (B) Conidiophores.

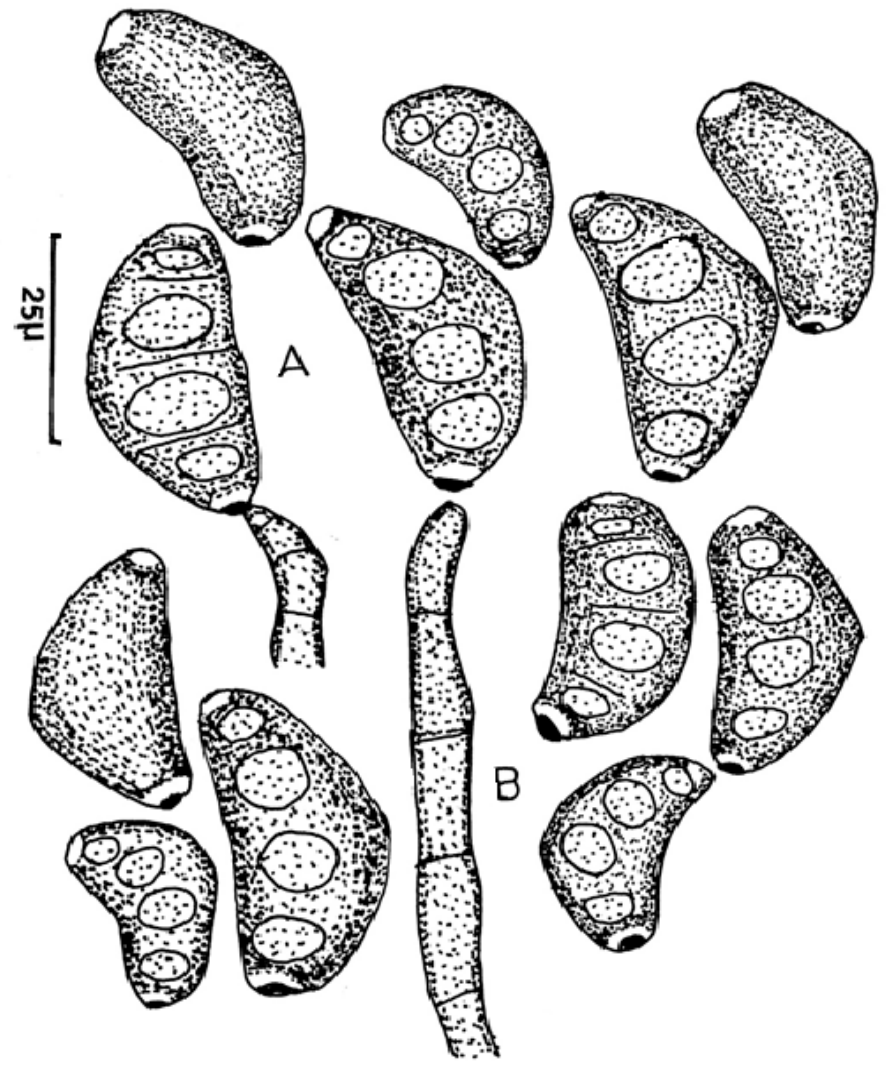

Fig. 10: Drechslera papendorfii (A) Conidia (B) Conidiophores 


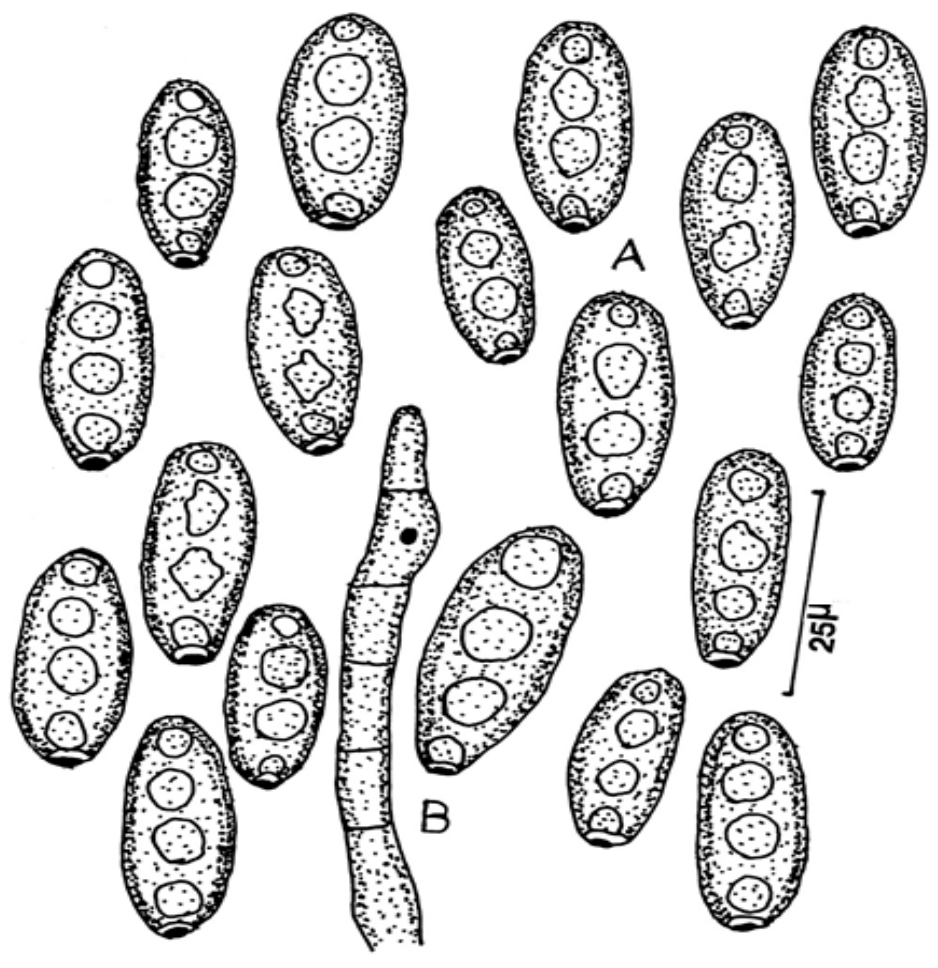

Fig. 11: Drechslera spicifera (A) Conidia (B) Conidiophores .

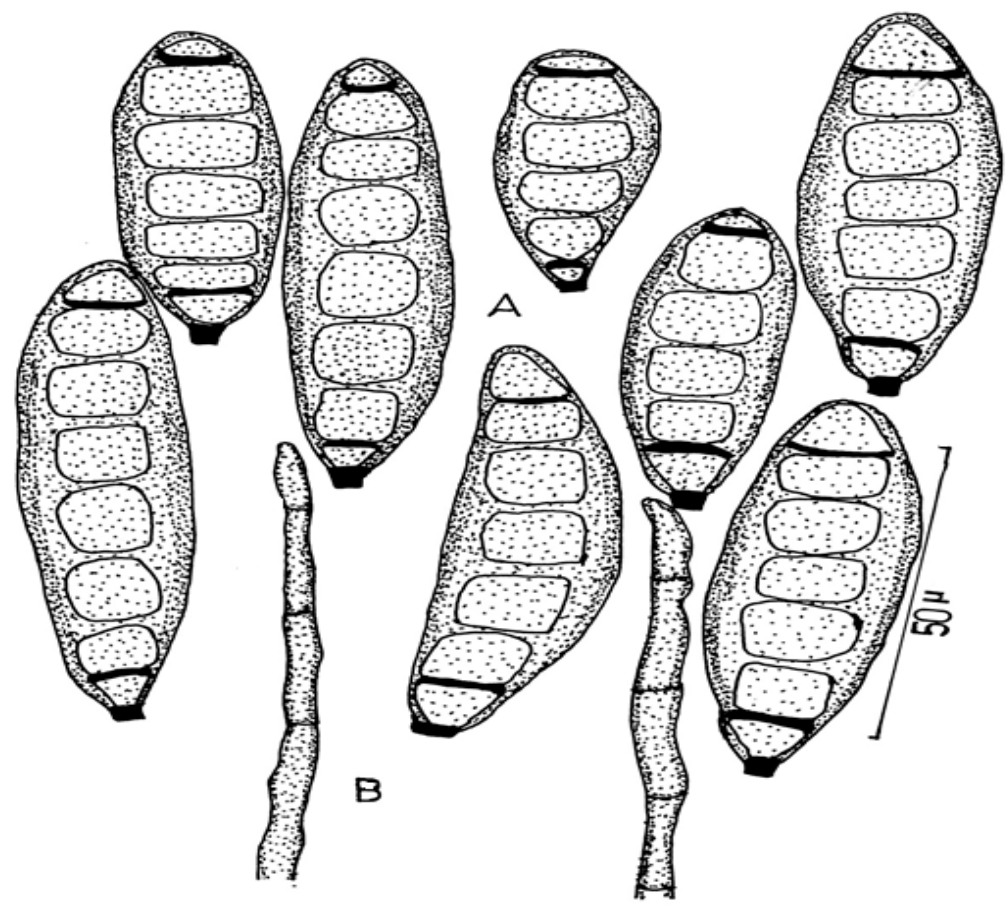

Fig. (12). Drechslera rostorata (A) Conidia (B) Conidiophores. 


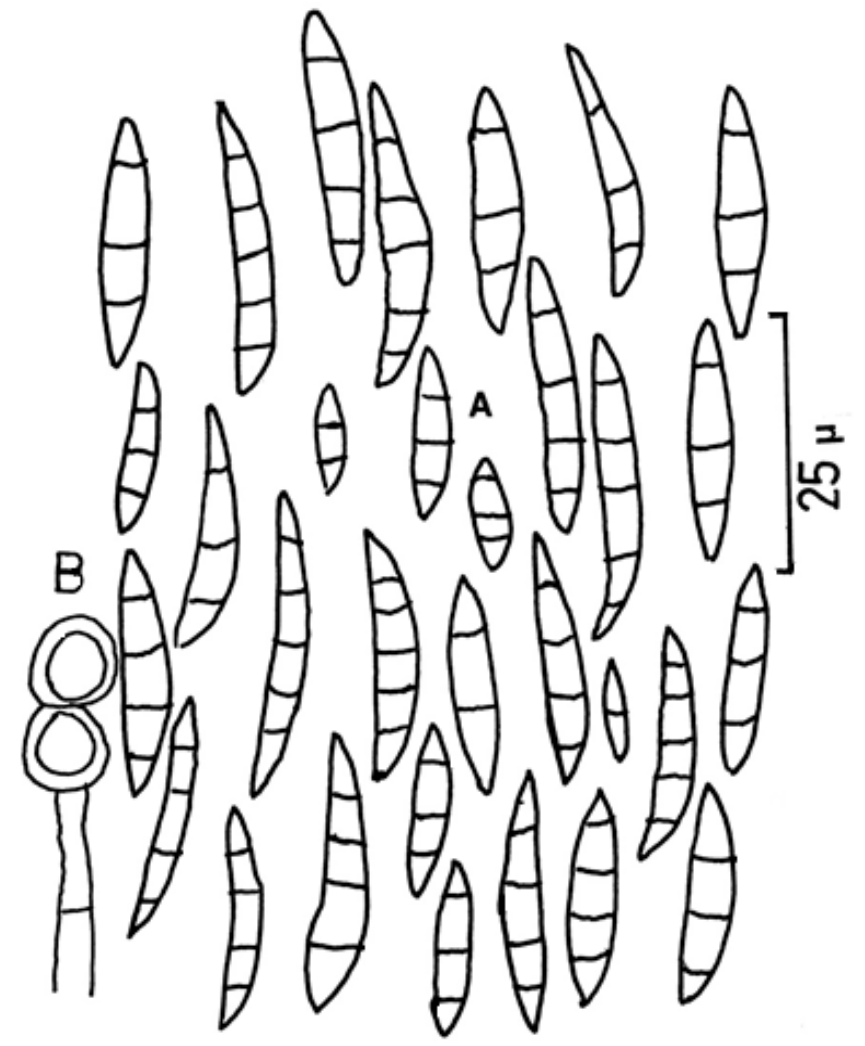

Fig. (13). Fusarium semitectum (A) Conidia (B) Chlamydospores..

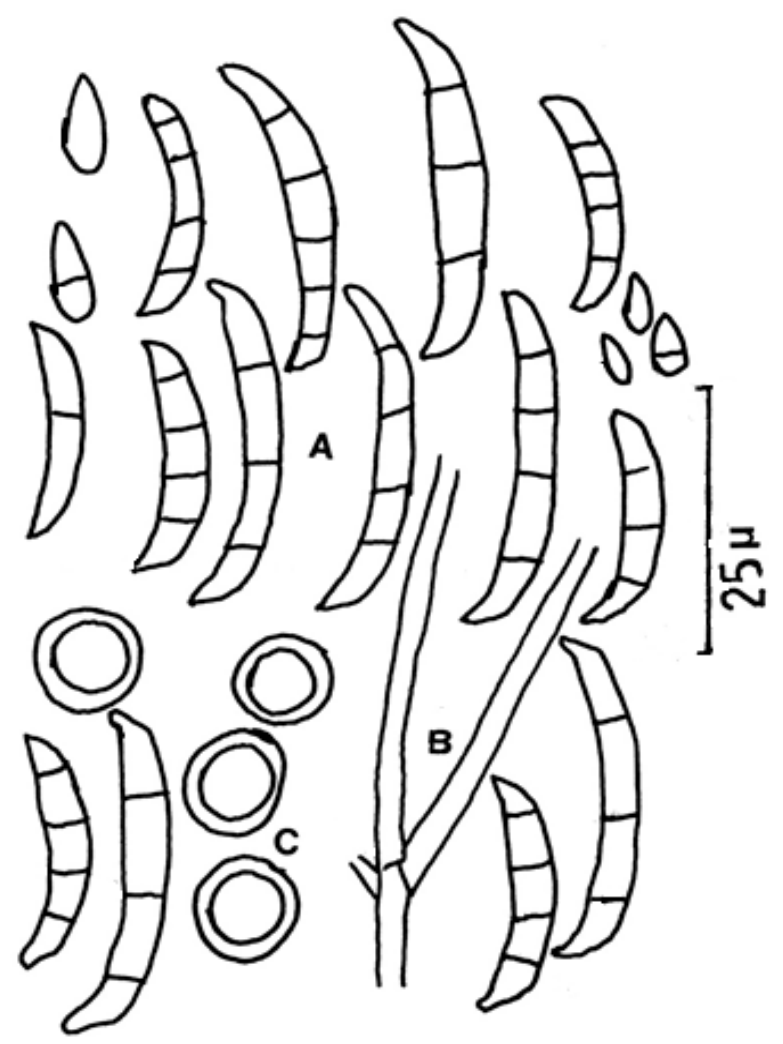

Fig. (14). Fusarium solani (A) Conidia (B) Conidiophores (C) Chlamydospores.. 


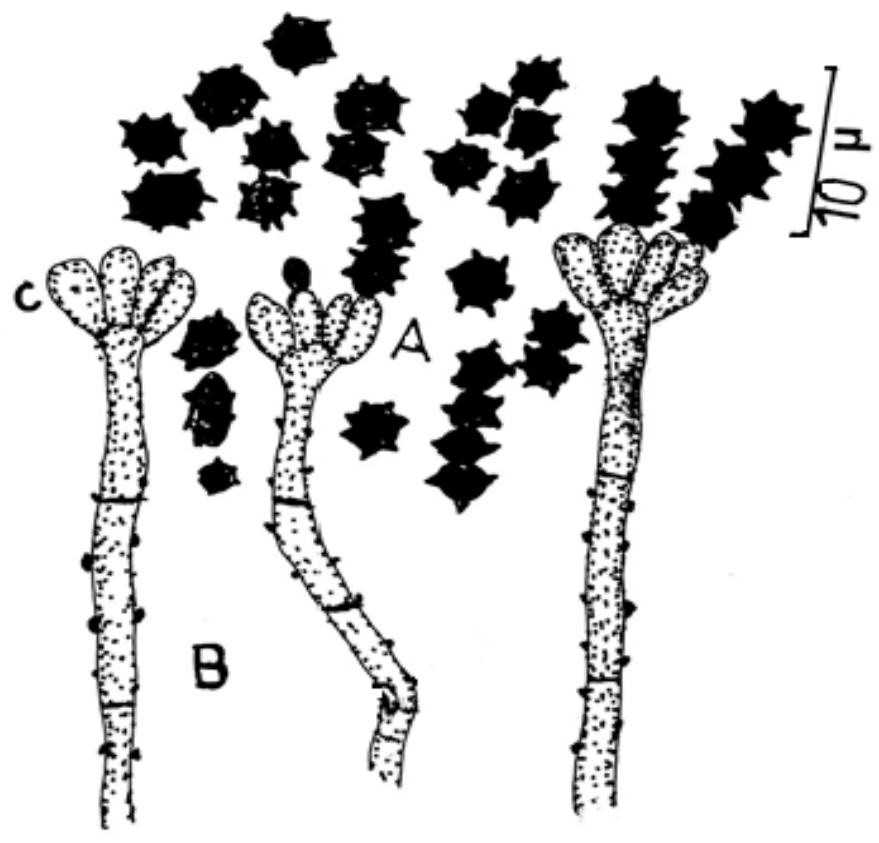

Fig. (15). Memnoniella echinata (A) Conidia (B) Conidiophores (C) Phialides.

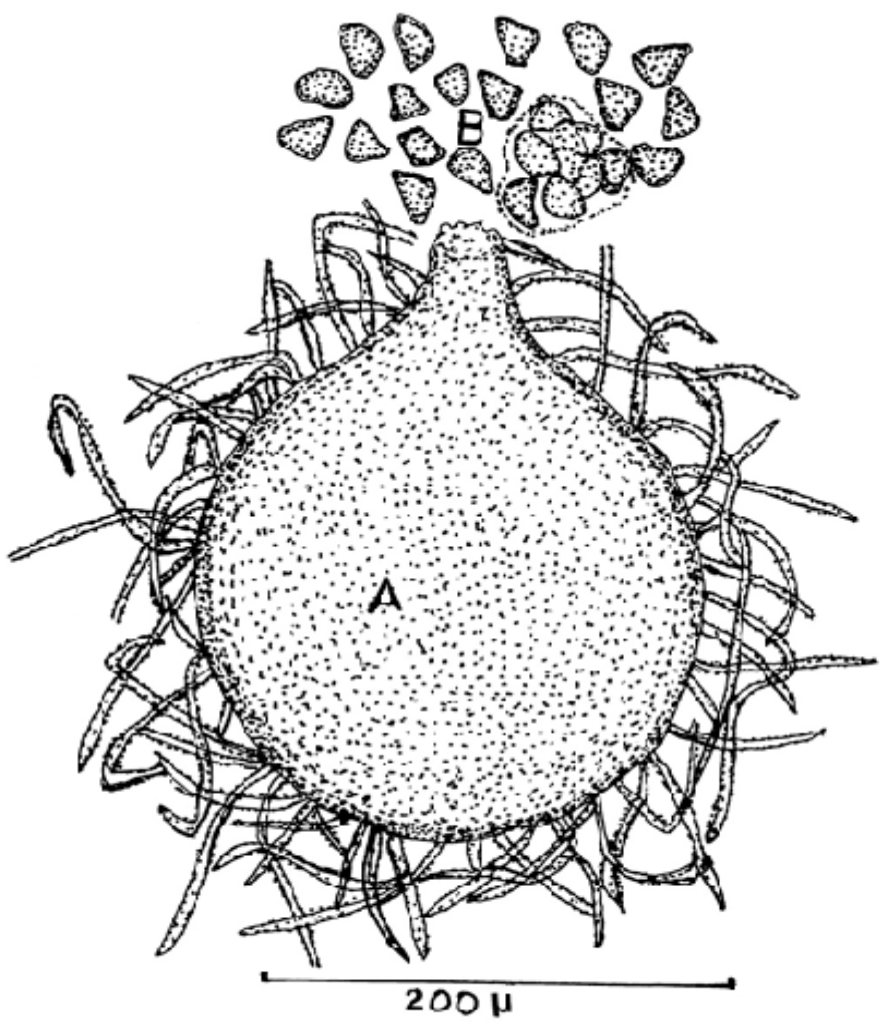

Fig. (16). Microascus trignosporus (A) Perithesium (B) Ascus and ascospores. 


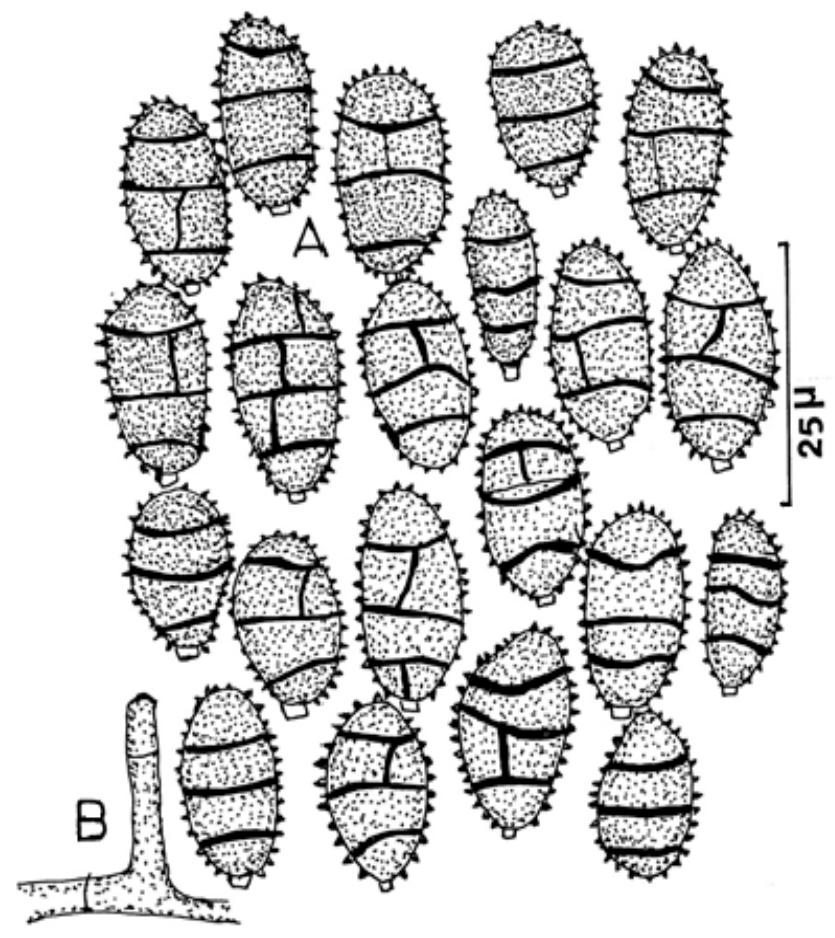

Fig. (17). Pithomyces chartarum (A) Conidia (B) Conidiophores.

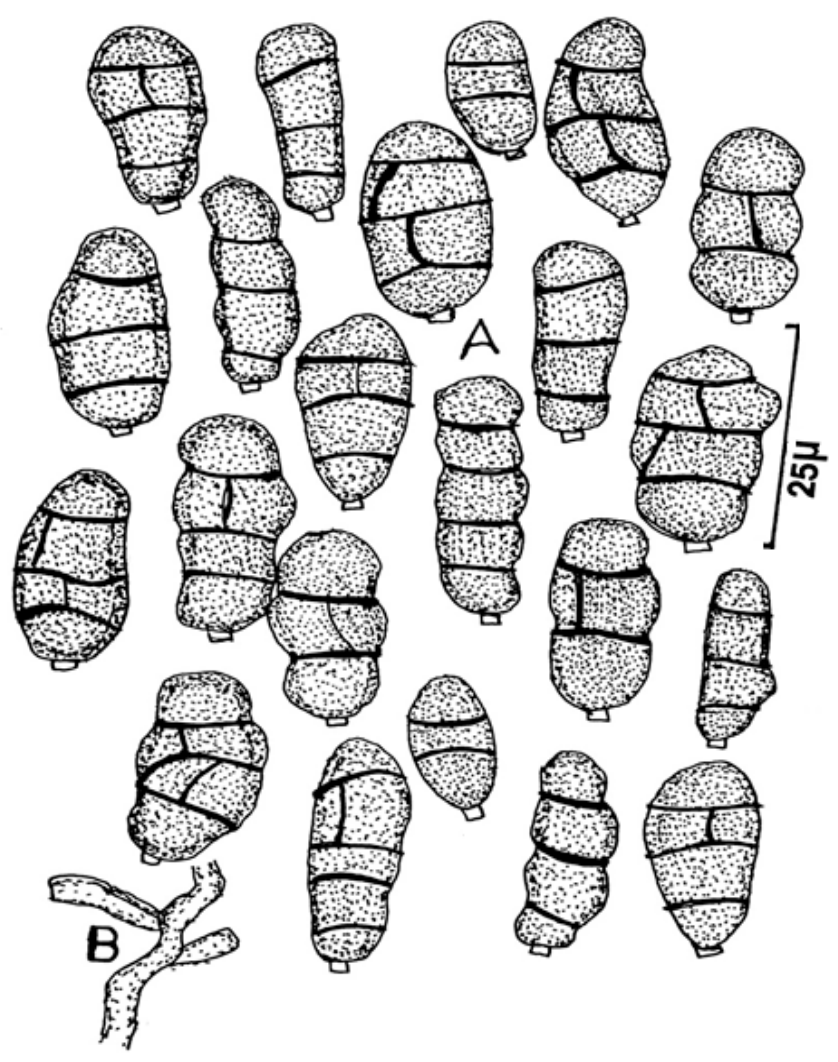

Fig. (18). Pithomyces sacchari (A) Conidia (B) Conidiophores. 


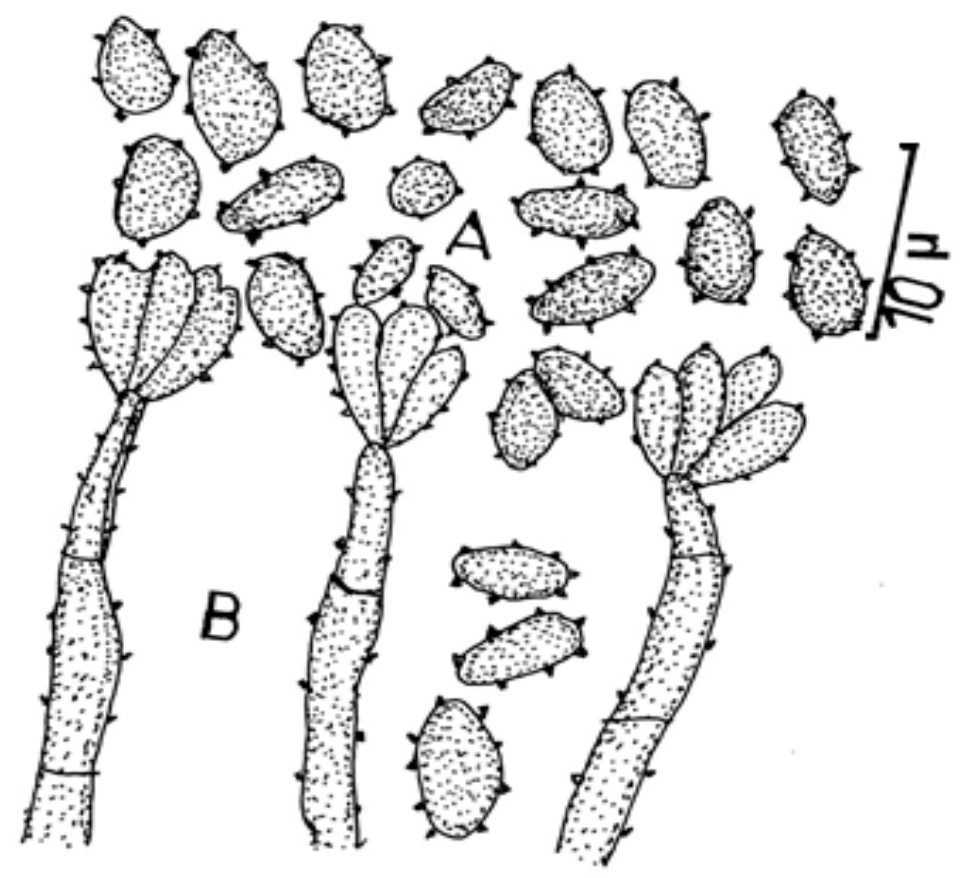

Fig. (19). Stachybotrys aurantes (A) Conidia (B) Conidiophores.

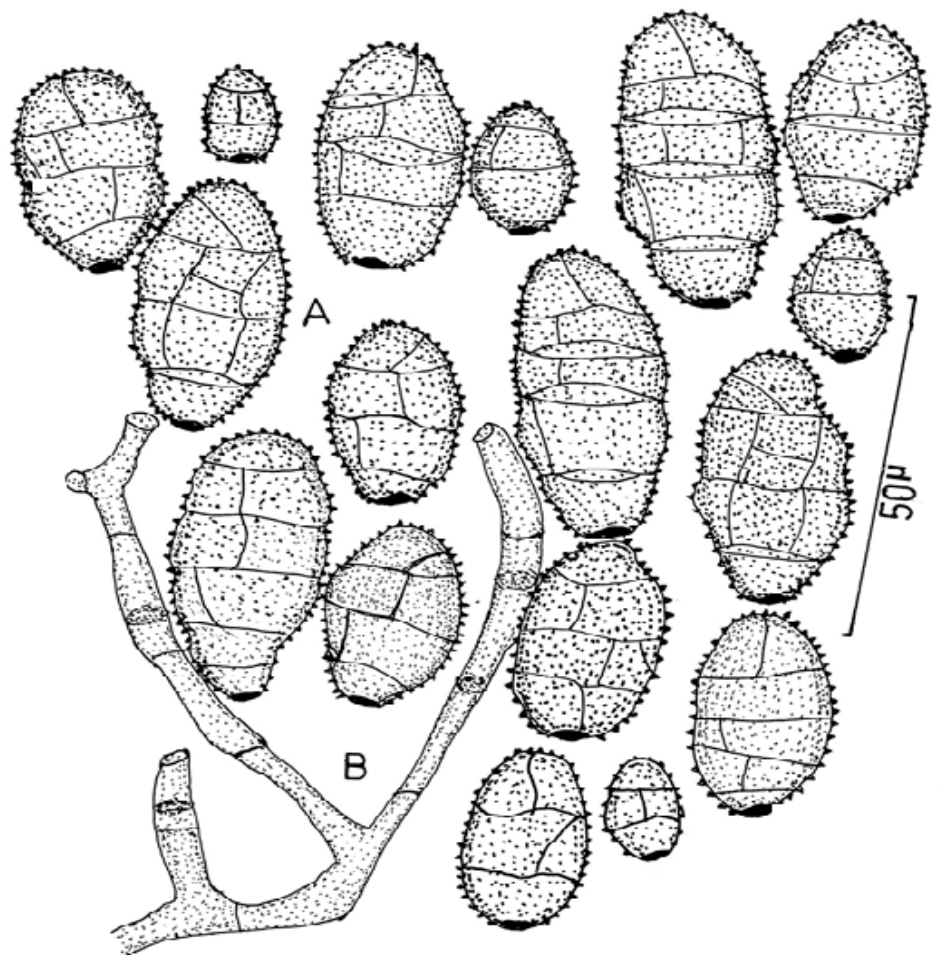

Fig. (20). Stemphylium botryosum (A) Conidia (B) Conidiophores. 


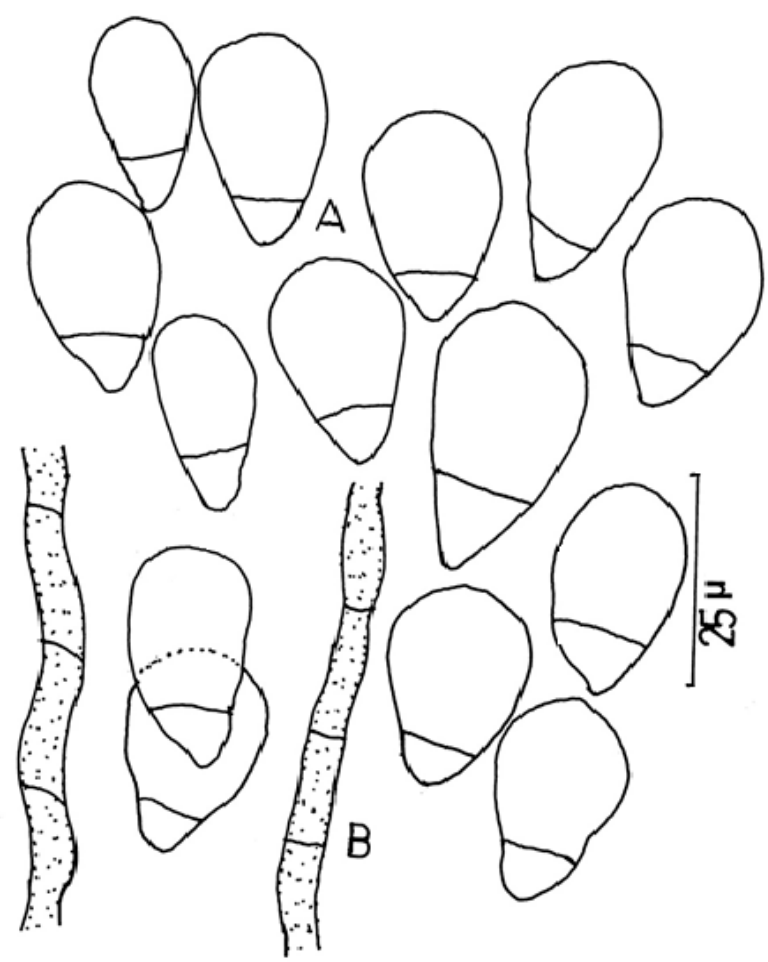

Fig. (21). Trichothecium roseum (A) Conidia (B) Conidiophores.

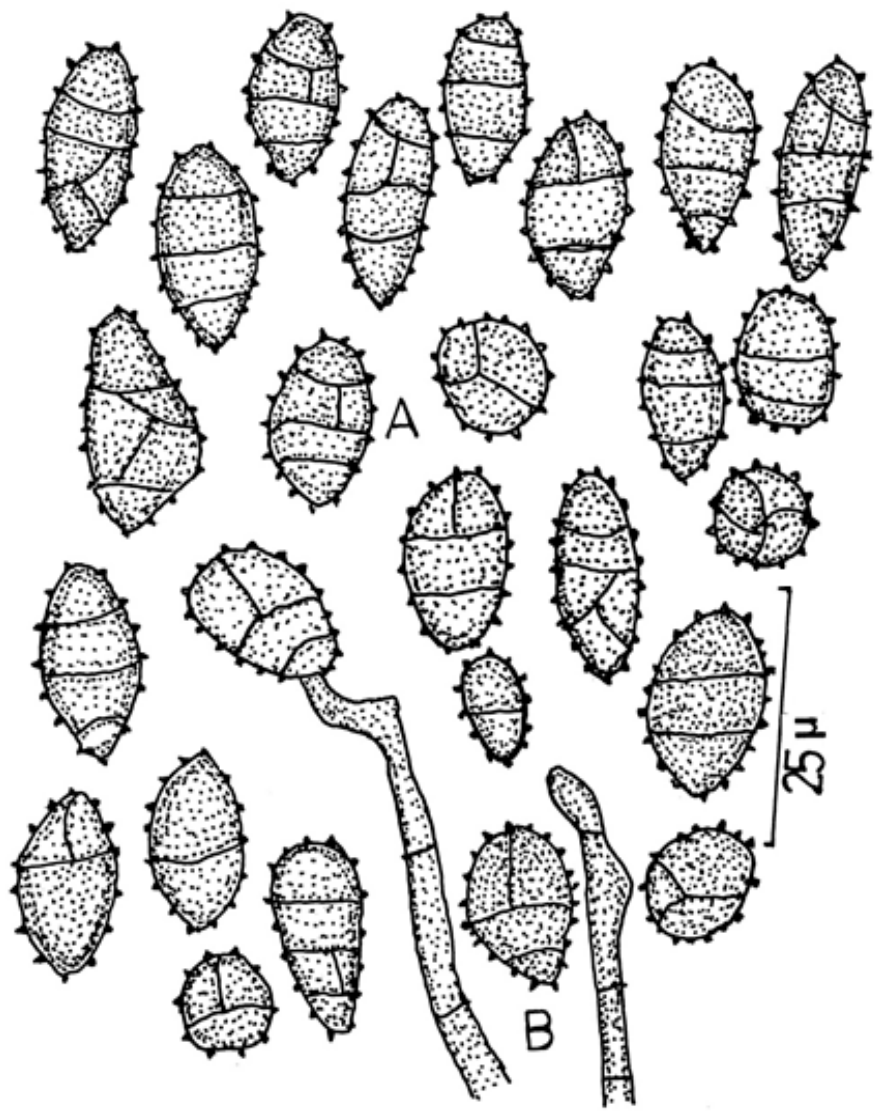

Fig. (22). Ulocladium botrytis (A) Conidia (B) Conidiophores. 


\section{REFRENCES}

[1] Robinson DS. Food biochemistry and nutritional value. New York: Longman Scientific and Technical Publisher; 1990.

[2] Hanif R, Igbal Z, Igbal M, Hanif S, Rasheed M. Uses of vegetables and nutritional food: Role in human health. J Agric Biol Sci 2006; 1(1): 18-22.

[3] Hell K, Gnonlonfin BGJ, Kodjogbe G, Lamboni Y, Abdourhamane IK. Mycoflora and occurrence of aflatoxin in dried vegetables in Berlin, Mali, and Togo, West Africa. Int J Food Microbiol 2009; 135: 99-104.

[4] Humphary CM, Clegg MS, Keen CL, Grivetti LE. Food diversity and drought survival. The hausa example. Int J Food Sci Nutr 1993; 44: 1-16.

[5] Gakou M, Force JE, Mclaughlen WJ. Non-timber forest product in Mali, study village use. Agrofor Syst 1994; 28: 213-26.

[6] Mertz O, Lykke AM, Reenberg A. Importance and seasonality of vegetable consumption and marketing in Burkina Faso. J Econ Bot 2001; 55: 276-89.

[7] Albashir HA, Imam MA. Status report on fruits and vegetables production and processing industry in Sudan AARDO workshop on technology on reducing post-harvest losses and maintaining quality of fruits and vegetables 2010; pp. 168-79.

[8] Badry AAK. Horticulture production in Sudan, past, present and future. Acta Hort 1984; 143: 25-9.

[9] Zakaria ZA, Somchit MN, Zaiton $\mathrm{H}$, et al. The in vitro antibacterial activity of Corchorus olitorius extracts. Int J Pharmacol 2006; 2(2): 213.

[10] Pal DK, Mandal M, Senthikumar GP, Padhirai A. Antibacterial activity of Cuscuta reflexa stem and Corchorus olitorius seed. Fitolterapia 2006; 77(7/8): 589-91.

[11] Yildiz A, Dogan MN, Boz Ö, Benlioglu S. Weed host of Verticillium dhlia Kleb in cotton fields in Turkey and characterization of $V$. dahliae from weeds. Phytoparasitica 2009; 37(2): 171-8.

[12] Noriel LM, Robles RP. Fungicidal activity of Portulaca oleracea L. extract against Helminthosporium maydis Nisik and Miyake in corn (Zea mays L.). Philipp J Weed Sci 1990; 17: 26-32.

[13] Banerjee G, Mukerjee A. Biological activity of a common weed Portulaca oleracea L. II. Antifungal activity. Acta Bot Hung 2002; 44(3/4): 205-8.

[14] Ramesh L, Nayaka HB. Phytochemical and antimicrobial activities of Portulaca oleracea L. J Pharm Res 2011; 4(10): 3553-5.

[15] Cerkauskas RF. Susceptibility of parsley cultivars to Septoria blight. Can J Plant Pathol 1991; 13(3): 273.

[16] Davis RM, Winterbottom CQ, Mircetich SM, Valencia J. First report of Phytophthora root rot of parsley. Plant Dis 1994; 78(11): 1122.

[17] Koike ST, Saenz GS. Occurrence of powdery mildews on parsley in California. Plant Dis 1994; 78(12): 1219.

[18] Delhey R, Kiehr M, Allievi MI, et al. Sclerotinia sclerotiorum infecting cultivated and invasive plants in Southern Pampas and Northern Patagonia. Argentina Phyton 2009; 78: 111-5.

[19] Soylu S, Soylu EM, Kurt S. Downy mildews outbreak of parsley caused by Plasmopora petroselini in Turkey. Plant Pathol 2010; 59: 799 .

[20] Kim KW. Identification of phytotoxins produced by Drechslera portulacae, a pathogen of purslane (Portulaca oleraceae).II. Isolation of zeaenol and its herbicidal activity. Korean J Weed Sci 1994; 14(3): 192-8.

[21] Eken C. Dichotomophthora portulacea on Portulaca oleracea in Turkey. Mycotaxon 2003; 87: 153-6.

[22] Gilardi G, Rossi j, Bertett D, Gullino ML, Gullino ML, Garibaldi A. Attacks of Phoma betae on Beta vulagris L. subsp. vulgaris in Northern Italy. Inf Fitopatol 2007: 57(12): 61-2.

[23] Campbell LG, Fugate KK, Niehaus WS. Fusarium yellows affects postharvest respiration rate, sucrose concentration and invert sugar in sugar beet. Am Soc Sugar Beet Technol 2011; 48(1/2); 17-39.

[24] Pérez Vincente L, Albreu FJ, Pérez MM, Martinez DE, Pueya FM. Efficacy of benomyl and fludioxonl in control of Verticillium alboatrum and V. dahliae in vegetable seeds. Fitosanidad 2011; 15(2): $107-15$.

[25] Nayak BK. Air and phylloplane mycoflora of Corchorus olitorius L. and C. capsularis L. J Palynol 1997; 33(1/2): 227-40.
[26] Sahu AK, Behera N. Surface and sub-surface mycoflora of jute (Corchorus olitorius and C. capsularis. Indian Phytopath 1966; 49(4): 393-7.

[27] Raghavendra VB, Lokesh S, Girisha ST, Govindappa M, Prakash HS. Antifungal activity of aqueous extract of safed musli against seed mycoflora of some crop species. Am Eurasian J Agric Environ Sci 2006; 1(2): 86-90.

[28] Amin RBMR, Rashid MM, Meah MB. Efficacy of garlic tablet to control seedborne fungal pathogen. J Agric Rural Dev 2009; 7 (12): $135-8$.

[29] Sultana N, Ghaffar A. Effect of fungicides, Microbial antagonists and oilcakes in control of Fusarium solani, the cause of seed rot, seedling and root infection of bottle gourd, blitter guord and cucumber. Pakistan J Bot 2010; 42(4): 2921-34.

[30] Abdel-Mallek AY. Seedborne fungi of five cruciferous vegetables and relative efficacy of aqueous seed extracts against some associated fungi. Assuit J Agric Sci 1994; 25(5): 251-60.

[31] Tonic S, Rovito D, Pra M dal, Nipoti P, Pancaldi D, Alberti I. Biomolecular characterization of Fusarium spp. strains isolated from Eruca sativa and Diplotuxis spp. seeds. Micologia Italiana 2009; 38(2): 13-23.

[32] Jain SC. Assessment of losses in taramira (Eruca sativa Lam) due to Alternaria blight disease. Madras Agric J 1992; 79(1): 57-8.

[33] Minuto G, Minuto A, Garibaldi A. Eruca sativa: Chemical control of downy mildews and white rust. Colture Protette 1997; 26(6): 616.

[34] Lima MLP, Cafefilho AC, Nogueira NL, Rossi ML, Schuta LR. First report on clubroot of Eruca sativa caused by Plasmodiophora brassicae. Plant Dis 2004; 88(5): 574.

[35] Gilardi G, Gullino ML, Garibaldi A. New pathogens on leafy vegetables grown in northern Italy for ready-to-eat-salads. Int Soc Plant Pathol 2010; 85: 39-44.

[36] Garibaldi A, Gilardi G, Bertoldo C, Gullino ML. First report of leave spot of rocket (Eruca sativa) caused by Fusarium equiseti in Italy. Plant Dis 2011; 95(10): 1315.

[37] Hajihassani M, Hajihassani A, Khaghani S. Incidence and distribution of seedborne fungi associated with wheat in Markazi Province, Iran. Afr J Biotechnol 2012; 11(23): 6290-5.

[38] ISTA. International rules for seed testing. Seed Sci Technol 1966 4: 3-49.

[39] El-Nagerabi SAF, Elshafie AE. Composition of mycoflora and aflatoxins in lupine seeds from the Sudan. Phytopathol Mediterr 2000; 39(2): 257-62.

[40] El-Nagerabi SAF, Elshafie AE. Determination of seedborne fungi and aflatoxins in Sudanese guar seeds. Trop Sci 2001; 41(1): 31-5.

[41] El-Nagerabi SAF. Determination of seedborne fungi and detection of aflatoxins in Sudanese fenugreek seeds. Phytoparasitica 2002 30 (1): 61-6.

[42] Raper KB, Fennell DI. The genus Aspergillus. Baltimore: Williams and Wilkins 1965.

[43] Pitt JI. The genus Penicillium and its Teleomorphic States Eupenicillium and Talaromyces. New York: Academic Press 1979.

[44] Ellis MB. Dematiaceous Hyphomycetes. Kew: Commonwealth Mycological Institute 1971.

[45] Ellis MB. More Dematiaceous Hyphomycetes. Kew: Commonwealth Mycological Institute 1976.

[46] Sutton BC. The Coelomycetes. London: Commonwealth Mycological Institute 1980.

[47] Samson RA, Hoekstra ES, Frisval JC, Filtenborg O. (1995) Introduction to Food-Borne Fungi. $5^{\text {th }}$ Ed. Baarn, Holland: Centraalbureau voor Schimmelcultures 1995; p. 322.

[48] Barnett HL, Hunter BB. Illustrated genera of imperfect fungi. $4^{\text {th }}$ Ed. New York; 1998.

[49] Barnett HL, Hunter BB. Illustrated genera of imperfect fungi. $4^{\text {th }}$ Ed. Minneapolis; 2003.

[50] Polevshchikov SI, Zavoloka IP. Degree of infection by Cercospora leaf spot and root rot incidence and foreign -bred sugar beet hybrids. Sakharnaya Srekla 2011; 6: 21-3

[51] Kamble P, Borkar GM, Patil DV. Study on seedborne pathogens of pumpkin, cucumber, watermelon and muskmelon. J Soil Crops 1999; 9(2): 234-8

[52] Menezes VO, Pedrosa DC, Piveta G, et al. Detection and influence of Fusarium spp. in physiological quality of cucumber seeds. Cienc Rural 2011; 41(2), Santa Maria Feb. 2011. Epub Feb 11, 2011. 
[53] El-Nagerabi SAF, Ahmed AHM. The effect of black mould (Aspergillus niger) on two Sudanese cultivars of onion. Trop Sci 2001; 41(2): 95-9.
[54] Richardson MJ. An annotated list of seed-borne diseases, $3^{\text {rd }}$ ed., Commonwealth Mycological Institute, as phytoapthological paper, No. 23, and ISTA handbook, section1.1; 1997.

Received: November 21, 2013

() Abdelwehab et al.; Licensee Bentham Open.

This is an open access article licensed under the terms of the Creative Commons Attribution Non-Commercial License (http://creativecommons.org/ licenses/by-nc/3.0/), which permits unrestricted, non-commercial use, distribution and reproduction in any medium, provided the work is properly cited. 